\title{
Antistaphylococcal activity of bacteriophage derived chimeric protein P128
}

\author{
Aradhana A Vipra', Srividya Narayanamurthy Desai ${ }^{1}$, Panchali Roy ${ }^{1}$, Raghu Patil', Juliet Mohan Raj', \\ Nagalakshmi Narasimhaswamy ${ }^{1,3}$, Vivek Daniel Paul ${ }^{1,2}$, Ravisha Chikkamadaiah ${ }^{1}$ and Bharathi Sriram ${ }^{*}$
}

\begin{abstract}
Background: Bacterial drug resistance is one of the most significant challenges to human health today. In particular, effective antibacterial agents against methicillin-resistant Staphylococcus aureus (MRSA) are urgently needed. A causal relationship between nasal commensal S. aureus and infection has been reported. Accordingly, elimination of nasal $S$. aureus reduces the risk of infection. Enzymes that degrade bacterial cell walls show promise as antibacterial agents. Bacteriophage-encoded bacterial cell wall-degrading enzymes exhibit intrinsic bactericidal activity. P128 is a chimeric protein that combines the lethal activity of the phage tail-associated muralytic enzyme of Phage $\mathrm{K}$ and the staphylococcal cell wall targeting-domain (SH3b) of lysostaphin.

Here we report results of in vitro studies evaluating the susceptibility of staphylococcal strains to this novel protein.

Results: Using the broth microdilution method adapted for lysostaphin, we found that P128 is effective against S. aureus clinical strains including MRSA, methicillin-sensitive S. aureus (MSSA), and a mupirocin-resistant S. aureus. Minimum bactericidal concentrations and minimum inhibitory concentrations of P128 (1-64 $\mu \mathrm{g} / \mathrm{mL})$ were similar across the $32 \mathrm{~S}$. aureus strains tested, demonstrating its bactericidal nature.

In time-kill assays, P128 reduced colony-forming units by $99.99 \%$ within $1 \mathrm{~h}$ and inhibited growth up to $24 \mathrm{~h}$. In an assay simulating topical application of P128 to skin or other biological surfaces, P128 hydrogel was efficacious when layered on cells seeded on solid media. P128 hydrogel was lethal to Staphylococci recovered from nares of healthy people and treated without any processing or culturing steps, indicating its in situ efficacy. This methodology used for in vitro assessment of P128 as an agent for eradicating nasal carriage is unique.

Conclusions: The novel chimeric protein P128 is a staphylococcal cell wall-degrading enzyme under development for clearance of $S$. aureus nasal colonization and MRSA infection. The protein is active against globally prevalent antibiotic-resistant clinical isolates and other clinically significant staphylococcal species including S. epidermidis. The P128 hydrogel formulation was bactericidal against Staphylococci including S. aureus recovered from the nares of 31 healthy people, demonstrating its in situ efficacy.
\end{abstract}

\section{Background}

Antibiotic-resistant Staphylococcus aureus strains emerging from the community as well as hospital environments represent a global threat $[1,2]$, requiring new approaches to control this pathogen. The anterior nare is the major reservoir of $S$. aureus in humans; $80 \%$ of the human population may be carriers [3]. A causal relationship between nasal colonization of $S$. aureus and serious infection has been established; thus, eliminating S. aureus nasal carriage

\footnotetext{
* Correspondence: bsriram@gangagen.com

'Gangagen Biotechnologies Pvt. Ltd., No. 12, 5th Cross, Raghavendra Layout,

Tumkur Road, Yeshwantpur, Bangalore 560 022, Karnataka, India

Full list of author information is available at the end of the article
}

may reduce the risk of infection $[4,5]$. Coagulase-negative Staphylococci (CoNS) are known commensal flora of the skin and mucous membranes and also colonize human anterior nares. Recently CoNS have been recognised as opportunistic pathogens responsible for the increasing incidence of serious nosocomial infections, mainly because of their affinity for the foreign materials used in prosthetics and indwelling devices. Immunocompromised patients, including those undergoing haemodialysis, are especially susceptible to these infections [6,7]. More than $80 \%$ of clinical CoNS strains and 30\% to $40 \%$ of CoNS obtained from healthy carriers or patients from the community are resistant to methicillin [8].

\section{() Biomed Central}

(c) 2012 Vipra et al; licensee BioMed Central Ltd. This is an Open Access article distributed under the terms of the Creative Commons Attribution License (http://creativecommons.org/licenses/by/2.0), which permits unrestricted use, distribution, and reproduction in any medium, provided the original work is properly cited. 
Bactroban Nasal (Mupirocin ointment) has been approved for nasal clearance of S. aureus and significantly reduces the risk of postoperative staphylococcal infection in carriers [9]. However, mupirocin resistance has already been reported, and its use is restricted in many countries. A superior product for intranasal prophylaxis in at-risk patients is therefore an unmet medical need. New chemical entities take longer to develop, and killing by broadspectrum antibiotics is undesirable. Current efforts are therefore focused on pathogen-specific biological entities such as peptidoglycan hydrolases [10], antibodies [11], and other antimicrobial peptides and proteins [12]. For example, lysostaphin is a bacterial peptidoglycan hydrolase that has been extensively studied for its antistaphylococcal activity in various animal models [13-15]. Bacteriophages are viruses that infect and kill bacteria and have coevolved with bacterial defenses [16]. Bacteriophages have been used for human therapy in several Eastern European countries for decades [17]. Although they have not been used in clinical applications in Western countries, the United States Food and Drug Administration recently approved the use of bacteriophages to prevent bacterial contamination in meat [18]. In addition, bacteriophages are a good source of cell wall-degrading enzymes, which have been evaluated as antibacterial agents [19-21].

P128 is a novel chimeric protein that derives its staphylococcal cell wall-degrading enzymatic domain from the gene product, ORF56, of bacteriophage $\mathrm{K}$ and the cell wall-targeting domain (SH3b) from Lysostaphin (Pubmed accession no. of Lysostaphin gene: M 15686.1). We have previously reported the construction of this novel chimeric protein and assignment of its peptidoglycan hydrolase activity to the Cysteine, Histidine-dependent AmidoHydrolase/peptidase (CHAP) domain. We also demonstrated the efficacy of P128 in nasal clearance of methicillin-resistant S. aureus (MRSA; strain USA300) in a rodent model [22]. P128 is under development for topical indications including use against $S$. aureus nasal carriage. In this study we tested the antistaphylococcal activity of P128 by determining minimum inhibitory concentration (MIC), minimum bactericidal concentration $(\mathrm{MBC})$, time-kill kinetics, and activity against Staphylococci from human nares.

\section{Methods}

\section{Bacterial strains}

All S. aureus strains used in the study are listed in Table 1. These include 30 clinical strains (27 MRSA strains and 3 MSSA strains) from the Public Health Research Institute, New Jersey and two USA 500 strains.

\section{P128 expression and purification}

P128 protein was cloned and expressed under the inducible T7 expression system in E. coli ER2566 strain.
Table 1 MIC and MBC of P128 against 32 Staphylococcus aureus strains

\begin{tabular}{|c|c|c|c|}
\hline SI. No. & Strain & MIC $(\mu \mathrm{g} / \mathrm{mL})$ & $\mathrm{MBC}(\mu \mathrm{g} / \mathrm{mL})$ \\
\hline 1 & BK\#13725 & 2 & 2 \\
\hline 2 & BK\#9894 & 2 & 4 \\
\hline 3 & BK\#2926 (USA100) & 2 & 8 \\
\hline 4 & BK\#13993 & 4 & 4 \\
\hline 5 & BK\#14035 & 4 & 16 \\
\hline 6 & BK\#12003 & 4 & 16 \\
\hline 7 & BK\#13385 & 4 & 32 \\
\hline 8 & BK\#15273 & 4 & 4 \\
\hline 9 & BK\#14942 & 4 & 4 \\
\hline 10 & BK\#19069 (USA300) & 4 & 8 \\
\hline 11 & BK\#11147 & 4 & 4 \\
\hline 12 & BK\#15271 & 4 & 4 \\
\hline 13 & BK\#14483 & 4 & $>32$ \\
\hline 14 & BK\# 13387 & 4 & 8 \\
\hline 15 & BK\#13228 & 8 & 8 \\
\hline 16 & BK\#14935 & 8 & 16 \\
\hline 17 & BK\# 13237 & 8 & 32 \\
\hline 18 & BK\#14655 & 8 & 8 \\
\hline 19 & BK\#18552 & 8 & 16 \\
\hline 20 & BK\#9897 C (USA400) & 8 & 8 \\
\hline 21 & BK\#14284 & 16 & 16 \\
\hline 22 & BK\#13180 & 16 & 16 \\
\hline 23 & BK\#8374 (COL) & 16 & 64 \\
\hline 24 & BK\#11512 & 16 & 16 \\
\hline 25 & BK\#11433 & 16 & 16 \\
\hline 26 & BK\#13641 & 16 & 64 \\
\hline 27 & BK\#2394 & 32 & 64 \\
\hline 28 & BK\#9918 & 1 & 1 \\
\hline 29 & BK\#14780 & 8 & 8 \\
\hline 30 & BK\#15383 & 16 & 16 \\
\hline 31 & USA500/1 & 16 & ND \\
\hline 32 & USA500/2 & 64 & ND \\
\hline 33 & S. carnosus, ATCC 51365 & 0.5 & 0.5 \\
\hline 34 & S. aureus, ATCC 25923 & 4 & 4 \\
\hline
\end{tabular}

MIC was determined using a modification of the CLSI broth microdilution method. P128 was tested at 256 to $0.125 \mu \mathrm{g} / \mathrm{mL}$. S. aureus ATCC 25923 and S. carnosus ATCC 51365 were used as control strains. MBC was determined following the CLSI procedure by plating $100 \mu \mathrm{L}$ from the MIC, MIC $\times 2$, MIC $\times$ 4 , and MIC $\times 8$ wells on LB agar, and incubating the plates overnight at $37^{\circ} \mathrm{C}$. Strains 1-30 constitute a global panel of distinct clinical isolates (MRSA, strains1-27; MSSA, strains 28-30) obtained from the Public Health Research Institute (NJ, USA); strains 31 and 32 are USA500.

Details of cloning and design of the P128 clone-construct were reported previously (22).

To generate a purified preparation of P128 for the studies reported in this work, expression of P128 protein in E. coli ER2566 was induced with $1 \mathrm{mM}$ IPTG, at $37^{\circ} \mathrm{C}$ for $4 \mathrm{~h}$. The induced cell pellet was lysed and the protein in the supernatant was subjected to $0-50 \%$ ammonium sulphate precipitation using solid ammonium sulphate at $4^{\circ} \mathrm{C}$. The precipitate was dialysed against $25 \mathrm{mM}$ Tris $\mathrm{HCl}$ buffer $\mathrm{pH}$ 8.0, passed through an anion exchange column. 
The unbound fraction (flow through), containing P128 protein, was bound to a cation exchange column using $50 \mathrm{mM}$ sodium acetate buffer at $\mathrm{pH}$ 6.0. The bound protein was eluted using a linear gradient of 0 to $0.5 \mathrm{M}$ sodium chloride. Fractions containing P128 protein were extensively dialysed against saline and used for all the studies.

\section{MIC and MBC}

The MIC was determined using a modified Clinical and Laboratory Standards Institute (CLSI) broth microdilution procedure [23]. Briefly, microtiter wells were precoated with $0.5 \%$ bovine serum albumin (BSA) to prevent nonspecific P128 adherence to the polystyrene plate, based on the method published for lysostaphin [24]. Two-fold dilutions of P128 were prepared in Mueller Hinton broth (MHB; Himedia) supplemented with $0.1 \%$ BSA (Sigma Aldrich), and $50 \mu \mathrm{L}$ aliquots of the P128 dilutions $(0.125-256 \mu \mathrm{g} / \mathrm{mL})$ were added to the wells. Bacterial suspensions (0.5 McFarland standard) were diluted in MHB to achieve $1 \times 10^{6}$ colony-forming units (CFU) per $\mathrm{mL}$. Then $50 \mu \mathrm{L}$ aliquots of the cell suspension were added to wells containing P128. Plates were incubated under static conditions at $35^{\circ} \mathrm{C}$ for $18 \mathrm{~h}$. The MIC was defined as the lowest concentration of P128 in which no visible growth was observed at the end of the incubation period. The MBC was also determined using the CLSI procedure. Briefly, $100 \mu \mathrm{L}$ from the MIC, two times MIC $($ MIC $\times 2)$, four times MIC $($ MIC $\times 4)$, and eight times MIC $(\mathrm{MIC} \times 8)$ wells were plated on Luria Bertani (LB) agar and incubated at $37^{\circ} \mathrm{C}$ overnight.

MIC of Vancomycin was determined for a panel of $S$. aureus isolates that represented the MIC range of P128 (1-64 $\mu \mathrm{g} / \mathrm{mL})$ using the CLSI broth microdilution method. Vancomycin was tested at concentrations of $0.125-256 \mu \mathrm{g} / \mathrm{mL}$, and MICs were read manually after $24 \mathrm{~h}$ of incubation. MBC was also determined using the CLSI procedure. The reference strain, $S$. aureus ATCC 25923 was used for quality control of the assay, in case of both P128 and Vancomycin MIC and MBC determinations.

\section{Time-kill curve studies}

The kinetics of P128 bactericidal activity were assessed in vitro using six S. aureus strains: BK\#13237, BK\#9894, BK\#14780, BK\#8374, BK\#9918, and BK\#19069. The cryopreserved test strains were plated on LB agar plate and incubated overnight at $37^{\circ} \mathrm{C}$. Several well-isolated colonies were picked up and suspended in MHB broth; the turbidity was then adjusted to $0.5 \mathrm{McFarland}$ standard (about $10^{8} \mathrm{CFU} / \mathrm{mL}$ ). The initial inoculum was prepared by inoculating $10 \mu \mathrm{L}$ of each test bacterial suspension into $20 \mathrm{~mL}$ MHB supplemented with $0.1 \%$ BSA. After $1 \mathrm{~h}$ in a shaker incubator $\left(37^{\circ} \mathrm{C}, 200 \mathrm{rpm}\right), 2.7 \mathrm{~mL}$ aliquots of the culture were dispensed into four tubes, and $0.3 \mathrm{~mL}$ P128 was added. A $0.3 \mathrm{~mL}$ aliquot was immediately removed to determine the initial CFU $(0 \mathrm{~h})$. Incubation was continued, and $0.3 \mathrm{~mL}$ aliquots were taken at $1,2,4$, 8 , and $24 \mathrm{~h}$. The cultures were serially diluted in sterile saline immediately after sampling and plated on $\mathrm{MHB}$ agar. After overnight incubation of the plates, CFU were determined. The time-kill curve was plotted based on bacterial survival at the sampling intervals [25].

\section{Efficacy of P128 hydrogel applied to S. aureus on agar surface}

P128 hydrogel was formulated with hydroxyethyl cellulose $(0.42 \%)$, propylene glycol $(0.75 \%)$, and glycerin $(2.25 \%)$ as the main excipients along with P128 protein. A formulation that contained physiological saline in place of P128 (referred to as buffer gel) served as a negative control. LB agar was poured into 24-well tissue culture plates (Tarson). S. aureus (BK\#13237) cells at $10^{3} \mathrm{CFU} /$ well (Figure 1 ) and $10^{2} \mathrm{CFU} /$ well (Figure 1) were seeded on LB agar in the microwells. P128 gel was diluted two-fold in buffer gel to contain P128 protein at a concentration range of 100 to $1.56 \mu \mathrm{g} / \mathrm{mL}$. P128 gel preparations were applied to wells and the plates were incubated at $37^{\circ} \mathrm{C}$ for $18 \mathrm{~h}$. At the end of incubation, $20 \mu \mathrm{L}$ iodonitrotetrazolium chloride (INT dye; Loba Chemie) prepared in $50 \mathrm{mM}$ sodium phosphate

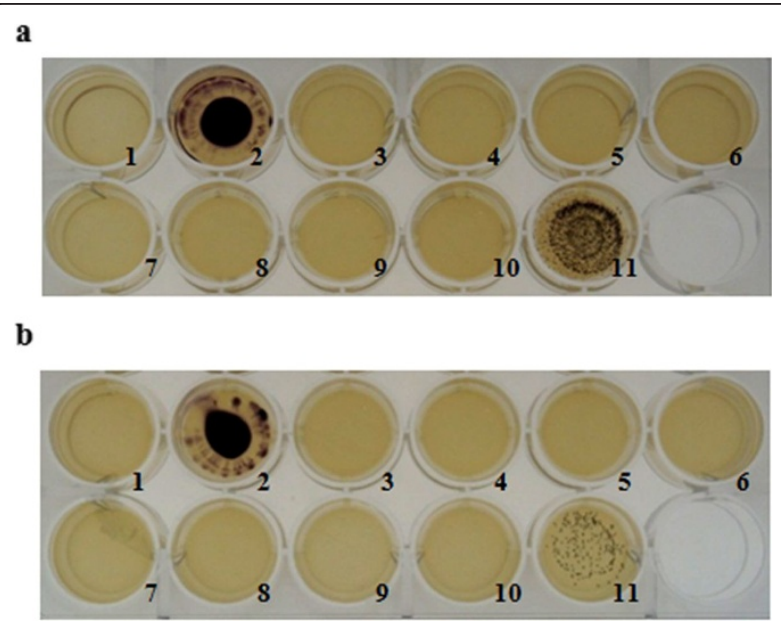

Figure 1 Efficacy of P128 gel formulation applied to $S$. aureus on agar surface. A hydrogel formulation containing P128 protein (100 to $1.56 \mu \mathrm{g} / \mathrm{mL}$ ) was tested for bactericidal activity when applied topically on S. aureus strain BK\#13237 cultured on LB agar: (a) $10^{3} \mathrm{CFU} /$ well, (b) $10^{2} \mathrm{CFU} /$ well. Well \#1 represents the media control, and well \#2 represents the cell control. In both (a) and (b), P128 gel preparations $(100-1.56 \mu \mathrm{g} / \mathrm{mL}$ ) were added to wells \#3-9; P128 protein formulated in physiological saline $(100 \mu \mathrm{g} / \mathrm{mL})$ was added in well \#10 as a positive control; buffer gel was added to well \#11 as a negative control. INT dye was added to the visualize growth of the surviving bacteria. 
buffer, $\mathrm{pH} 7.0(30 \mathrm{mg} / \mathrm{mL})$ was added to the wells to visualize viable cells.

\section{Bactericidal activity of P128 in simulated nasal fluid}

Activity of P128 was tested in a buffer that simulated the ionic composition of nasal fluid. The simulated nasal fluid (SNF) contained $0.87 \% \mathrm{NaCl}, 0.088 \% \mathrm{CaCl}_{2} .2 \mathrm{H}_{2} \mathrm{O}, 0.31 \%$ $\mathrm{KCl}$, and $0.636 \% \mathrm{BSA}[26]$. The S. aureus COL strain was subcultured in LB medium from an overnight culture and grown at $37^{\circ} \mathrm{C}$ and $200 \mathrm{rpm}$ until the $\mathrm{OD}_{600}$ reached 1.0 to $1.5\left(5 \times 10^{8} \mathrm{CFU} / \mathrm{mL}\right) .100 \mu \mathrm{L}$ of this cell suspension $\left(5 \times 10^{7} \mathrm{CFU}\right)$ was centrifuged at $3000 \times \mathrm{g}$ for $10 \mathrm{~min}$ and the cell pellet was suspended in $100 \mu \mathrm{L}$ of SNF. $100 \mu \mathrm{L}$ of P128 prepared in SNF $(1.5 \mu \mathrm{g} / \mathrm{mL})$ was added to the cells. As a positive control, P128 contained in physiological saline was added to cells suspended in physiological saline. After addition of P128, tubes were incubated for $1 \mathrm{~h}$ in a shaker incubator at $37^{\circ} \mathrm{C}, 200 \mathrm{rpm}$. Cells were then pelleted and resuspended in $1 \mathrm{~mL} \mathrm{LB}$, and 10-fold dilutions were plated on LB agar and incubated at $37^{\circ} \mathrm{C}$ overnight. Cells treated with SNF or saline served as untreated cell controls.

\section{Efficacy of P128 gel on nasal Staphylococci in their native physiological state}

Nasal commensal Staphylococci of 31 healthy people were characterized and evaluated for sensitivity to P128. A dry swab (Copan Diagnostics) was inserted into each nostril, rotated six times to cover the entire mucosal surface of the anterior nare, and slowly withdrawn. The swab from one nostril of each individual was immersed in a vial containing $200 \mu \mathrm{L}$ P128 hydrogel $(40 \mu \mathrm{g} / 200 \mu \mathrm{L})$, and a swab from the other nostril was immersed in a vial containing $200 \mu \mathrm{L}$ buffer gel (control). The vials were placed in a biosafety cabinet for $1 \mathrm{~h}$ at ambient temperature (about $25^{\circ} \mathrm{C}$ ). The entire vial contents were then spread on blood agar plates and incubated overnight at $37^{\circ} \mathrm{C}$. CFUs recovered were characterized in terms of colony morphology, hemolysis on blood agar, Gram stain, and a HiStaph identification kit (Himedia).

\section{Results and discussion}

P128 is a bacteriophage derived staphylococcal cell-wall degrading enzyme. This protein is under development in our laboratory for topical therapeutic use in humans. In this study, we tested the bactericidal activity of P128 protein on globally prevalent $S$. aureus clinical strains. We assessed the biological activity of P128 using various in vitro assays and under conditions designed to simulate physiological conditions.

P128 protein preparations used in this study were of > 95\% purity. The protein expressed was in the soluble form in a standard E. coli expression system and purified using a 2-step ion-exchange chromatography procedure [22].
Susceptibility to P128 determined by MIC and MBC assay Determination of MIC and MBC is a commonly used method to assess susceptibility to antimicrobial agents. We determined the MIC and MBC of P128 for a panel of 31 globally represented strains of $S$. aureus using modified CLSI methods [23]. Microtiter plate wells were precoated with BSA before adding P128 to minimize nonspecific adherence and loss of protein to the polypropylene surface. The MIC of P128 for the various strains of S. aureus ranged from 1 to $64 \mu \mathrm{g} / \mathrm{mL}$ (Table 1 ). The MIC at which $50 \%$ of the strains tested were inhibited $\left(\mathrm{MIC}_{50}\right)$ was $8 \mu \mathrm{g} / \mathrm{mL}$. The MBC of P128 across $S$. aureus strains tested also ranged from 1 to $64 \mu \mathrm{g} / \mathrm{mL}$; and the $\mathrm{MBC}_{50}$ was found to be $16 \mu \mathrm{g} / \mathrm{mL}$ (Table 1).

MIC and MBC of Vancomycin were determined using the same procedure that was used in case of P128. For the reference strain, S. aureus ATCC $25923 \mathrm{MIC}$ and MBC of Vancomycin was found be $0.5 \mu \mathrm{g} / \mathrm{mL}$ and $2 \mu \mathrm{g} / \mathrm{mL}$ respectively. These values correlate with the reported MIC and $\mathrm{MBC}$ of Vancomycin for this strain, validating the assay used in this work. Vancomycin was also tested on a panel of $S$. aureus strains that represented the MIC range of P128 (1 to $64 \mu \mathrm{g} / \mathrm{mL}$ ). MIC of Vancomycin for these strains ranged from 0.5 to $1 \mu \mathrm{g} / \mathrm{mL}$ and $\mathrm{MBC}$ ranged from 1 to $4 \mu \mathrm{g} / \mathrm{mL}$ (Table 2 ).

Strains 1-6 were selected from a globally represented panel of distinct, typed clinical isolates (MSSA, strain 1; MRSA, strains 2-7) obtained from The Public Health Research Institute, New Jersey, USA; strain 7 is USA500/2, and 8 is $S$. aureus, ATCC 25923

Since MIC relates to growth inhibition activity of an antimicrobial agent, $\mathrm{MBC}$ may be a more appropriate measure of activity of P128 which is bactericidal in action.

\section{Table 2 MIC and MBC of Vancomycin against a panel of} S. aureus isolates

\begin{tabular}{llll}
\hline SI. No. & Strain & Vancomycin \\
\cline { 3 - 4 } & & MIC $(\boldsymbol{\mu g} / \mathrm{mL})$ & MBC $(\mu \mathrm{g} / \mathrm{mL})$ \\
\hline $\mathbf{1}$ & BK\#9918 & 0.5 & 2 \\
$\mathbf{2}$ & BK\# 2926 & 1 & 1 \\
$\mathbf{3}$ & BK\#19069 & 1 & 4 \\
$\mathbf{4}$ & BK\#9897 & 1 & 4 \\
$\mathbf{5}$ & BK\#8374 & 1 & 4 \\
$\mathbf{6}$ & BK\#2394 & 1 & 4 \\
$\mathbf{7}$ & USA500/2 & 1 & 4 \\
$\mathbf{8}$ & S. aureus, ATCC 25923 & 0.5 & 2 \\
\hline
\end{tabular}

MIC was determined by modified broth microdilution method following the CLSI procedure. Vancomycin test concentration was in the range of 256 to $0.125 \mu \mathrm{g} / \mathrm{mL}$. S. aureus ATCC 25923 was used as the control strain. MBC was determined following the CLSI procedure by plating $100 \mu \mathrm{L}$ from the MIC, MIC $\times 2, \mathrm{MIC} \times 4$ and MIC $\times 8$ wells on LB agar and incubating the plates at $37^{\circ} \mathrm{C}$ overnight. The strains used here span the MIC range of P128. 


\section{Time-kill curve studies}

Time-kill assays were performed in accordance with the CLSI guidelines, with a starting inoculum of $5 \times 10^{4}$ $\mathrm{CFU} / \mathrm{mL}$ and, various multiples of the MICs. The objective of this assay was to evaluate concentration-dependent bactericidal activity. In order to find the optimal concentration required to achieve and maintain > 99.99\% killing upto $24 \mathrm{~h}$, sub-MIC levels were not considered. The detection limit of the time kill curve was $10 \mathrm{CFU} / \mathrm{mL}$.

We determined the number of viable $S$. aureus cells remaining at different time intervals after adding P128 protein. Figure 2 shows the time-kill curves of P128 for six representative strains of $S$. aureus, which included five MRSA strains and one MSSA strain. P128 showed rapid, dose-dependent bactericidal activity against the MSSA and MRSA strains tested, killing of $99.99 \%$ of cells in all six strains tested within $1 \mathrm{~h}$ at the respective MIC concentration. At the MIC, growth was inhibited up to $24 \mathrm{~h}$ for all five MRSA strains and up to $8 \mathrm{~h}$ for the MSSA strain (BK\#9918). However, the cells of BK\#9918 that grew after $8 \mathrm{~h}$ were susceptible to P128 (data not shown). Since a concentration $4 \times$ the MIC inhibited growth of this strain for up to $24 \mathrm{~h}$, we surmised that higher concentrations of P128 or repeated treatments may be required in such cases.

\section{Efficacy of P128 gel formulation applied to S. aureus on agar surface}

The efficacy of P128 hydrogel was tested on solid culture medium to simulate the conditions of topical nasal application.

The assay format was designed to check availability of the protein when applied as a gel formulation. The objective was also to test efficacy of P128 gel applied to a surface where low numbers of bacterial cells are present. We have used a range of $100-1 \mu \mathrm{g} / \mathrm{mL}$ of protein concentration in the gel formulation. P128 gel showed complete clearance at concentrations up to $1.56 \mu \mathrm{g} / \mathrm{mL}$ (Figure 1).

\section{Bactericidal activity of P128 against S. aureus COL in SNF} Functional efficiency and structural stability of enzymes can generally be influenced by $\mathrm{pH}$, temperature, and the composition and concentrations of metal or inorganic ions in the reaction milieu. Our primary concern was that monovalent and divalent ions present in nasal fluid may have a deleterious effect on P128 activity. We therefore evaluated the activity of P128 in a composition that simulated the ionic content of normal human nasal fluid. We found that P128 reduced the staphylococcal viable count (CFU) by five orders of magnitude in SNF, comparable to the activity observed in case of P128 in physiological saline. Cells incubated in SNF that did not contain
P128 were unaffected (Figure 3). These results indicate that the protein would not be influenced by the ionic content of human nasal fluid.

\section{Efficacy of P128 gel on nasal Staphylococci in their native physiological state}

Secreted products and components such as exotoxins, exoenzymes, surface-associated adhesins, and capsular polysaccharide play a role modulating host responses to S. aureus infection [27]. Production of capsular polysaccharide type 5 by Staphylococci has been reported in a study using a mouse model of $S$. aureus nasal colonization [28]. The same study also showed the inability of a capsule-defective mutant to persist in mouse nares, indicating that $S$. aureus is encapsulated in the nares. The rate of methicillin resistance among CoNS isolates colonizing anterior nares of patients undergoing haemodialysis is reported to be higher than that of S. aureus isolates; this is accompanied by the lack of susceptibility to other classes of antibiotics [7]. Although S. epidermidis is responsible for most CoNS infections, other CoNS species have been associated with a variety of human diseases [6]. For example, S. haemolyticus is the second most commonly encountered species in clinical infections, and S. lugdunensis is a more recently described CoNS species [29].

In this context, we evaluated the bactericidal activity of P128 on S. aureus and other staphylococcal species recovered from human nares. As the first step, we characterized the nasal commensal bacteria of 31 healthy people. Speciation was carried out using the HiStaph identification kit and the $S$. aureus carriage rate was also determined. Nasal Staphylococci of $71 \%$ of the healthy people sampled consisted of CoNS species, predominantly S. epidermidis and $S$. aureus was found in the remaining $29 \%$ of people. Other CoNS among nasal commensal bacteria included S. haemolyticus and S. lugdunensis (Table 3). We examined nasal commensal populations in two randomly selected healthy people for comparability between the two nares with respect to bacterial load and staphylococcal species present and found both nares to be comparable (data not shown).

Commensal bacteria recovered from nasal swabs of 31 healthy people were plated on blood agar, enumerated, and characterized by Gram stain, coagulase test, and speciation

We then evaluated the activity of P128 hydrogel on nasal Staphylococci of 31 healthy people.

In case of nasal swabs immersed in buffer-gel, colonies were numerous, ranging from $10^{3}-10^{5}$ CFU; estimated based on results of a preliminary experiment, where $S$. aureus cells of known CFU counts $\left(10^{3}, 10^{4}\right.$ and $10^{5}$ $\mathrm{CFU}$ ) were plated to vizualize the pattern of growth after overnight incubation of plates (data not shown). Of the swabs immersed in P128 hydrogel, 4/31 showed > 99.99\% 


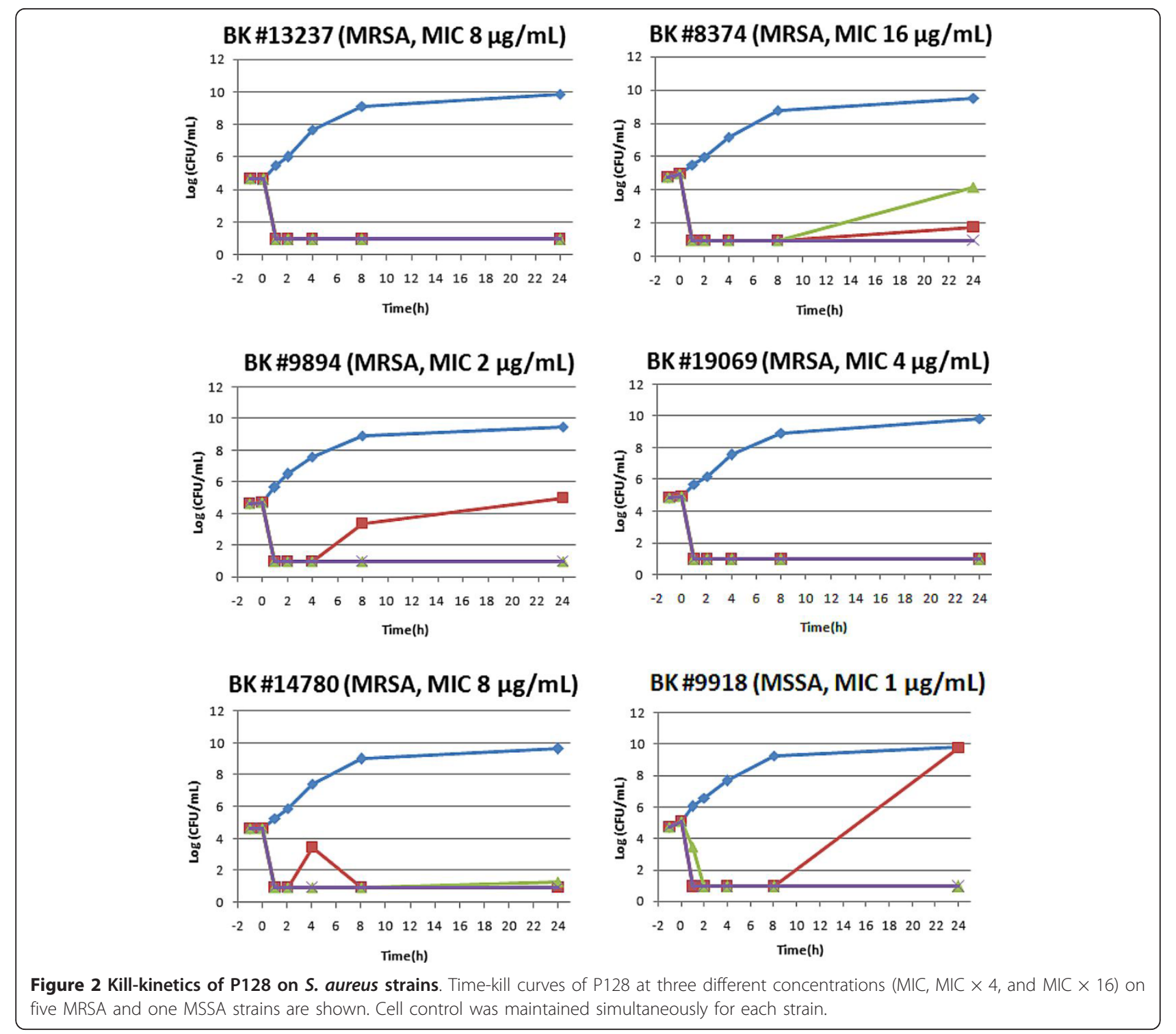

reduction in staphylococcal cell counts, 17/31 showed $99.9 \%$ reduction, $5 / 31$ showed $99 \%$ reduction, and $5 / 31$ showed $90 \%$ reduction (Table 4 ). A few colonies that grew on the plate containing P128 were found to be sensitive to the protein when tested, and hence apparently escaped the protein action.

This finding shows that P128 is bactericidal to nasal staphylococcal isolates. However, we did not evaluate the presence of capsular polysaccharides, which may be assessed in future studies in our laboratory. It is important to note that the cells were treated with P128 hydrogel immediately after isolation (i.e., without exposure to any other medium or subjection to any steps of cultivation). We conclude that both S. aureus and CoNS are susceptible to P128 in the physiological state relevant to nasal carriage. Considering the pathogenic potential and multidrug resistance of these species, it is significant that these species were fully sensitive to P128. Further studies are needed to determine the MIC and MBC of P128 on CoNS.

Reports point to the endogenous origin of most infective $S$. aureus isolates and MRSA carriage poses an increased risk for invasive infections compared with MSSA carriage [30,31]. The worldwide spread of MRSA strains, which are often multidrug-resistant [32], combined with limited therapeutic options necessitates new approaches to combat this pathogen. Recent findings emphasize that commensal CoNS strains are also potential threats [33]. Therefore an antibacterial agent, exemplified by $\mathrm{P} 128$, which can target antibiotic resistant S. aureus as well as other clinically significant Staphylococci would meet the current medical need and warrants further development. 


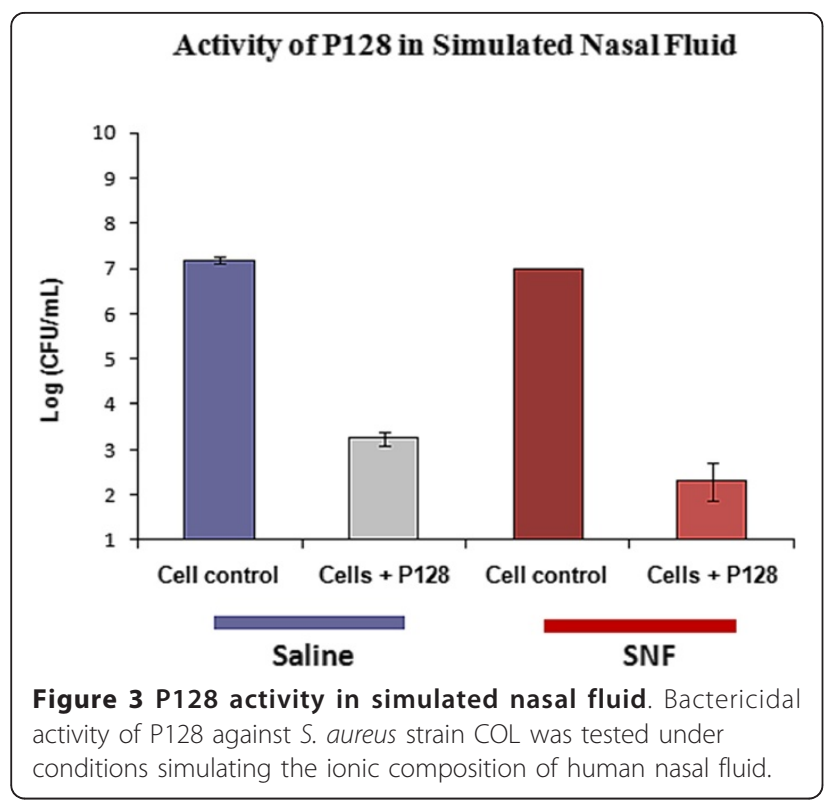

\section{Conclusions}

This report describes the development and in vitro biological characterization of a chimeric antistaphylococcal protein designated P128, which exhibits rapid and selective antibacterial activity at low MIC values against a broad range of staphylococcal species, including numerous clinically relevant $S$. aureus strains.

The MIC and MBC of P128 on a global panel of clinical isolates ranged from 0.5 to $64 \mu \mathrm{g} / \mathrm{mL}$. P128 showed in vitro microbicidal activity against a wide variety of staphylococcal species, including many clinically relevant $S$. aureus strains. With an $\mathrm{MBC}_{50}$ of $16 \mu \mathrm{g} / \mathrm{mL}$, the protein was bactericidal against every $S$. aureus strain tested. P128 time-kill kinetics were determined at MIC and higher concentrations on select isolates, and P128 was found to rapidly reduce cell numbers by $99.99 \%$. To

Table 3 Speciation of nasal commensal Staphylococci of healthy people

\begin{tabular}{lll}
\hline & Staphylococci recovered from healthy people & $\%$ \\
\hline \multicolumn{2}{l}{ Coagulase-positive } & $\mathbf{2 9 \%}$ \\
\hline $2 / 31$ & S. aureus & $6.4 \%$ \\
$5 / 31$ & S. aureus, S. epidermidis & $16.12 \%$ \\
$1 / 31$ & S. aureus, S. intermedius & $3.2 \%$ \\
$1 / 31$ & S. aureus, S. epidermidis, & $3.2 \%$ \\
& S. haemolyticus & \\
& Coagulase-negative & $\mathbf{7 1 \%}$ \\
$17 / 31$ & S. epidermidis & $54.8 \%$ \\
$2 / 31$ & S. lugdunensis & $6.4 \%$ \\
$1 / 31$ & S. delphini, S. epidermidis & $3.2 \%$ \\
$1 / 31$ & S. auricularis, S. epidermidis & $3.2 \%$ \\
$1 / 31$ & S. delphini & $3.2 \%$ \\
\hline
\end{tabular}

Table 4 Efficacy of P128 gel on nasal Staphylococci in their native physiological state

\begin{tabular}{|c|c|c|c|}
\hline \multirow[t]{2}{*}{ Volunteer No. } & \multicolumn{2}{|c|}{ CFU count } & \multirow[t]{2}{*}{ Reduction in CFU (\%) } \\
\hline & Buffer gel & P128 gel & \\
\hline 1 & $\sim 10^{5}$ & 16 & 99.99 \\
\hline 2 & $\sim 10^{5}$ & 10 & 99.99 \\
\hline 3 & $\sim 10^{5}$ & 18 & 99.99 \\
\hline 4 & 15 & 0 & $>99.99$ \\
\hline 5 & $\sim 10^{5}$ & 150 & 99.90 \\
\hline 6 & $>10^{5}$ & 143 & 99.90 \\
\hline 7 & $\sim 10^{5}$ & 212 & 99.90 \\
\hline 8 & $\sim 10^{4}$ & 57 & 99.90 \\
\hline 9 & $\sim 10^{4}$ & 15 & 99.90 \\
\hline 10 & $\sim 10^{4}$ & 13 & 99.90 \\
\hline 11 & $\sim 10^{4}$ & 14 & 99.90 \\
\hline 12 & $\sim 10^{4}$ & 44 & 99.90 \\
\hline 13 & $\sim 10^{4}$ & 57 & 99.90 \\
\hline 14 & $>10^{4}$ & 86 & 99.90 \\
\hline 15 & $\sim 10^{4}$ & 29 & 99.90 \\
\hline 16 & $\sim 10^{4}$ & 10 & 99.90 \\
\hline 17 & $\sim 10^{4}$ & 64 & 99.90 \\
\hline 18 & $\sim 10^{3}$ & 3 & 99.90 \\
\hline 19 & $\sim 10^{3}$ & 2 & 99.90 \\
\hline 20 & $\sim 10^{3}$ & 3 & 99.90 \\
\hline 21 & $\sim 10^{3}$ & 6 & 99.90 \\
\hline 22 & $>10^{5}$ & 1200 & 99.00 \\
\hline 23 & $\sim 10^{4}$ & 128 & 99.00 \\
\hline 24 & $\sim 10^{4}$ & 220 & 99.00 \\
\hline 25 & $\sim 10^{3}$ & 24 & 99.00 \\
\hline 26 & $\sim 10^{3}$ & 22 & 99.00 \\
\hline 27 & $\sim 10^{3}$ & 190 & 90.00 \\
\hline 28 & $\sim 10^{3}$ & 110 & 90.00 \\
\hline 29 & $\sim 10^{3}$ & 310 & 90.00 \\
\hline 30 & 278 & 17 & 90.00 \\
\hline 31 & 250 & 22 & 90.00 \\
\hline
\end{tabular}

Both nares of each individual were swabbed. One swab was immersed in P128 hydrogel, and the other was immersed in buffer gel (control). Staphylococcal CFU counts of nasal swabs immersed in P128 gel were significantly lower than CFU counts of control swabs

develop P128 as a treatment to eliminate human nasal carriage, P128 was formulated as a hydrogel and tested on nasal Staphylococci recovered from healthy people. The protein was able to kill S. aureus under conditions representing physiological conditions. Taken together, our findings demonstrate that P128 exhibits excellent antistaphylococcal properties and warrants development for therapeutic use.

\section{Acknowledgements}

The authors thank Dr. J Ramachandran for his support, review of data and key suggestions in this work. The authors would like to acknowledge the scientific staff at Gangagen, whose help and cooperation aided in the completion of this work. The authors thank Dr. Barry Kreiswirth, PHRI, New 
Jersey for providing global panel of S. aureus isolates and Dr. M. Jayasheela for reviewing the manuscript.

\section{Author details}

'Gangagen Biotechnologies Pvt. Ltd., No. 12, 5th Cross, Raghavendra Layout, Tumkur Road, Yeshwantpur, Bangalore 560 022, Karnataka, India. 2Department of Molecular Genetics, University of Toronto, 1 King's College Circle, Toronto, ON, M5S 1A8, Canada. ${ }^{3}$ Lecturer, Department of Microbiology, Melaka Manipal Medical College, Manipal Campus, Manipal 576 104, Karnataka, India.

\section{Authors' contributions}

$\mathrm{BS}$ and $\mathrm{AV}$ participated in the study design and coordination and data interpretation. AV, SD, PR and RP evaluated the efficacy of P128 gel in nasal Staphylococci experiments. JR, RP, PR, SD, and NN performed P128 MIC and MBC assays. JR and PR performed time-kill curve experiment. VP tested P128 activity in SNF, and RC evaluated the efficacy of P128 hydrogel in the agar surface assays. AV also helped draft the manuscript. All authors read and approved the final manuscript.

\section{Competing interests}

The authors declare that they have no competing interests.

Received: 5 October 2011 Accepted: 22 March 2012

Published: 22 March 2012

\section{References}

1. Steinberg JP, Clark CC, Hackman BO: Nosocomial and community acquired Staphylococcus aureus bacteremias from 1980 to 1993: impact of intravascular devices and methicillin resistance. Clin Infect Dis 1996, 23:255-259.

2. Kourbatova EV, Halvosa JS, King MD, Ray SM, White N, Blumberg HM: Emergence of community-associated methicillin-resistant Staphylococcus aureus USA 300 clone as a cause of health care-associated infections among patients with prosthetic joint infections. Am J Infect Control 2005, 33:385-391.

3. Kluytmans J, van Belkum A, Verbrugh H: Nasal carriage of Staphylococcus aureus: epidemiology, underlying mechanisms, and associated risks. Clin Microbiol Rev 1997, 10(3):505-520.

4. Kluytmans J, Mouton J, Yzerman E, Vandenbroucke-Grauls C, Maat A, Maat A, Wagenvoort, Verbrugh H: Nasal carriage of Staphylococcus aureus as a major risk factor for wound infections after cardiac surgery. J Infect Dis 1995, 171:216-219.

5. Heiman FL, Wertheim, Melles Damian C, Vos Margreet C, van Leeuwen Willem, Alex van Belkum, Verbrugh Henri A, Nouwen Jan L: The role of nasal carriage in Staphylococcus aureus infections. Lancet Infect Dis 2005, 5(12):751-762.

6. Huebner J, Goldmann DA: Coagulase negative Staphylococci: role as pathogens. Annu Rev Med 1999, 50:223-236.

7. De Mattos EM, Teixeira LA, Alves VM, Rezenda e Resende CA, da Silva Coimbra MV, da Silva-Carvalho MC, Ferreira-Carvalho BT, Figueiredo AM: Isolation of methicillin-resistant coagulase-negative Staphylococci from patients undergoing continuous ambulatory peritoneal dialysis (CAPD) and comparison of different molecular techniques for discriminating isolates of Staphylococcus epidermidis. Diagn Microbiol Infect Dis 2003, 45(1):13-22

8. Diekema DJ, Pfaller MA, Schmitz FJ, Smayevsky J, Bell J, et al: Survey of infections due to Staphylococcus species: frequency of occurrence and antimicrobial susceptibility of isolates collected in the United States, Canada, Latin America, Europe, and the Western Pacific region for the SENTRY Antimicrobial Surveillance Program, 1997-1999. Clin Infect Dis 2001, 32(Suppl 2S):114-132.

9. Van Rijen M, Bonten M, Wenzel R, Kluytmans J: Mupirocin ointment for preventing Staphylococcus aureus infections in nasal carriers. Cochrane Database Syst Rev 2008, 8(4):CD006216.

10. Maliničová L, Piknová M, Pristaš $P$, Javorský $P$ : Peptidoglycan hydrolases as novel tool for anti-enterococcal therapy. In Current Research, Technology and Education Topics in Applied Microbiology and Microbial Biotechnology. The Formatex Microbiology Book Series. Volume 1. Edited by: Mendes-Vilas A. Badajoz, Spain: Formatex Research Center; 2010:463-472.
11. Projan SJ, Nesin M, Dunman PM: Staphylococcal vaccines and immunotherapy: to dream the impossible dream? Curr Opin Pharmacol 2006, 6:473-479.

12. Gordon YJ, Romanowski EG, Mcdermott AM: A Review of Antimicrobial Peptides and Their Therapeutic Potential as Anti-Infective Drugs. Curr Eye Res 2005, 30(7):505-515.

13. Kokai-Kun JF, Walsh SM, Chanturiya T, Mond JJ: Lysostaphin Cream Eradicates Staphylococcus aureus Nasal Colonization in a Cotton Rat Model. Antimicrob Agents Chemother 2003, 47(5):1589-1597.

14. Kumar JK: Lysostaphin:an antistaphylococcal agent. App/ Microbiol Biotechnol 2008, 80:555-561.

15. Kokai-Kun JF, Chanturiya T, Mond JJ: Lysostaphin eradicates established Staphylococcus aureus biofilms in jugular vein catheterized mice. $J$ Antimicrob Chemother 2009, 64:94-100.

16. Deresinski S: Bacteriophage Therapy: Exploiting Smaller Fleas. Clin Infect Dis 2009, 48:1096-1101.

17. Soothill JS, Hawkins C, Anggard EA, Harper DR: Therapeutic use of bacteriophages. Lancet Infect Dis 2004, 4:544-545.

18. Lang L: FDA approves use of bacteriophages to be added to meat and poultry products. Gastroenterology 2006, 131(5):1370.

19. Loessner MJ: Bacteriophage endolysins-current state of research and applications. Curr Opin Microbiol 2005, 8:480-487.

20. Fischetti VA: Bacteriophage lytic enzymes: novel anti-infectives. Trends Microbiol 2005, 13:491-496.

21. Donovan DM, Lardeo M, Foster-Frey J: Lysis of Staphylococcal mastitis pathogens by bacteriophage phi11 endolysin. FEMS Microbiol Lett 2006, 265(1):133-139.

22. Paul VD, Rajagopalan SS, Sundarrajan S, George SE, Asrani JY, Pillai R, Chikkamadaiah R, Durgaiah M, Sriram B, Padmanabhan S: A novel Bacteriophage Tail Associated Muralytic Enzyme (TAME) from Phage $\mathrm{K}$ and its development into a potent antistaphylococcal protein. BMC Microbiol 2011, 11:226

23. National Committee for Clinical Laboratory Standards: Methods for determining Bactericidal Activity of Antimicrobial Agents; Approved Guideline. Approved Guideline M26-A. NCCLS, Wayne, PA; 1999.

24. Kusuma CM, Kokai-Kun JF: Comparison of four methods for determining lysostaphin susceptibility of various strains of Staphylococcus aureus. Antimicrob Agents Chemother 2005, 49:3256-3263.

25. Petersen PJ, Wang TZ, Dushin RG, Bradford PA: Comparative in vitro activities of AC98-6446, a novel semisynthetic glycopeptide derivative of the natural product mannopeptimycin alpha, and other antimicrobial agents against Gram-positive clinical isolates. Antimicrob Agents Chemother 2004, 48:739-746.

26. Vanthanouvong $V$, Roomans GM: Methods for Determining the Composition of Nasal Fluid by X-Ray Microanalysis. Microsc Res Tech 2004, 63(2):122-128

27. Ferry $T$, Perpoint $T$, Vandenesch F, Etienne J: Virulence determinants in Staphylococcus aureus and their involvement in clinical syndromes. Curr Infect Dis Rep 2005, 7:420-428.

28. Kiser KB, Cantey-Kiser JM, Lee JC: Development and characterization of a Staphylococcus aureus nasal colonization model in mice. Infect Immun 1999, 67:5001-5006.

29. Kloos WE, Bannerman TL: Update on Clinical Significance of CoagulaseNegative Staphylococci. Clin Microbiol Rev 1994, 7(1):117-140.

30. Eiff CV, Becker K, Machka K, Stammer H, Peters G: Nasal Carriage as a Source of Staphylococcus aureus Bacteremia Study Group. N Engl J Med 2001, 344:11-16

31. Lamers RP, Stinnett JW, Muthukrishnan G, Parkinson CL, Cole AM: Evolutionary analyses of Staphylococcus aureus identify genetic relationships between nasal carriage and clinical isolates. PLoS One 2011, 6(1):e16426.

32. Gordon RJ, Lowy FD: Pathogenesis of Methicillin-Resistant Staphylococcus aureus. Clin Infect Dis 2008, 46(Supplement 5):350-359.

33. Ruppé E, Barbier F, Mesli Y, Maiga A, Cojocaru R, Benkhalfat M, Benchouk S, Hassaine H, Maiga I, Diallo A, Koumaré AK, Ouattara K, Soumaré S, Dufourcq JB, Nareth C, Sarthou JL, Andremont A, Ruimy R: Diversity of Staphylococcal Cassette Chromosome mec Structures in MethicillinResistant Staphylococcus epidermidis and Staphylococcus haemolyticus Strains among Outpatients from Four Countries. Antimicrob Agents Chemother 2009, 53(2):442-449. 
doi:10.1186/1471-2180-12-41

Cite this article as: Vipra et al: Antistaphylococcal activity of

bacteriophage derived chimeric protein P128. BMC Microbiology 2012

12:41.

Submit your next manuscript to BioMed Central and take full advantage of:

- Convenient online submission

- Thorough peer review

- No space constraints or color figure charges

- Immediate publication on acceptance

- Inclusion in PubMed, CAS, Scopus and Google Scholar

- Research which is freely available for redistribution

Submit your manuscript at 